ISSN $1978-3000$

\title{
Pengaruh Pemberian Produk Fermentasi dari Bacillus Subtilis Terhadap Kadar Nitrogen, Asam Urat dan Amonia dalam Feses Broiler
}

\author{
Effect Of Fermented Product From Bacillus Subtili On Nitrogen Uric Acid And Ammonia \\ in Broiler Faeces
}

Urip Santoso

Jurusan Peternakan Fakultas Pertanian Universitas Bengkulu

Jalan Raya Kandang Limun, Bengkulu. Telp. (0736) 2170 pst.219.

\begin{abstract}
The present study was conducted to evaluate effect of fermented product from Bacillus subtilis (FPBS) on uric acid, nitrogen and ammonia in broiler faeces. Forty broiler chickens aged 7 days were distributed to 4 treatment groups as follows: One treatment group was fed diet contained 0\% FPBS as the control grup, and other three treatment groups were fed diet contained $0.5 \%, 1 \%$ or $2 \%$ FPBS, respectively. Experimental results showed that N-urate content of faeces in broiler chickens fed 1\% FPBS was the lowest at week 2 after treatment, whereas 2\% FPBS supplementation was the highest. Supplementation of $2 \%$ FPBS had the higher N-ammonia at week 2 and week 3 after treatment. Supplementation $1 \%$ or $2 \%$ FPBS reduced ammonia gas release at week 4 after treatment. Furthermore, the present results showed that supplementation of FPBS had no effect on the contents of nitrogen, uric acid and ammonia in faeces. In conclusion, supplementation of $1-2 \%$ FPBS to diet decreased ammonia gas release.
\end{abstract}

Key words: Bacillus subtilis, nitrogen, ammonia, uric acid

\begin{abstract}
ABSTRAK
Penelitian ini bertujuan untuk mengevaluasi pengaruh produk fermentasi dari Bacillus subtilis (PFBS) terhadap kadar asam urat, total nitrgen dan amonia dalam feses broiler. Empat puluh ekor ayam broiler umur 7 hari dibagi menjadi 4 kelompok perlakuan, yaitu 0\% PFBS (Kontrol), 0,5\% PFBS, 1\% PFBS dan 2\% PFBS. Hasil penelitian menunjukkan bahwa N-urate pada broiler yang diberi 1\% PFBS pada minggu kedua adalah yang terendah. Pemberian 2\% PFBS mempunyai N-urate yang tertinggi. Pemberian $2 \%$ PFBS pada mingu kedua dan ketiga mempunyai kadar $\mathrm{N}$-amonia yang lebih tinggi daripada kelompok lainnya. Pemberian $1 \%$ atau $2 \%$ PFBS menurunkan produksi gas amonia pada minggu keempat. Lebih lanjut hasil penelitian menunjukkan bahwa PFBS berpengaruh tidak nyata terhadap kadar nitrogen total, asam urat dan amonia dalam feses. Dapat disimpulkan bahwa pemberian 1-2\% PFBS mampu menurunkan produksi gas amomia.
\end{abstract}

Kata kunci: Bacillus subtilis, nitrogen, amonia, asam urat

\section{PENDAHULUAN}

Senyawa nitrogen yang berasal dari industri peternakan unggas merupakan salah satu senyawa penyebab polusi, sebagai kegiatan mikrorganisme yang mengubah asam urat menjadi gas amonia (Holthuijzen, 1993). Gas amonia merupakan gas yang menyebabkan iritasi dan merupakan gas yang banyak ditemukan dalam kandang unggas. Amonia menyebabkan perubahan jaringan pada sistem pernafasan dan meningkatkan infeksi mikoplasma (Broderson et al., 1976) dan menurunkan pertumbuhan. Selain itu, amonia dalam tanah akan dikonversikan ke dalam nitrat oleh bakteri nitrat, sehingga mengakibatkan $\mathrm{pH}$ air tanah turun dan tingginya kadar nitrat dalam air minum. Meskipun dalam kadar yang 
rendah, gas amonia juga menyumbangkan peningkatan suhu bumi.

Mempertimbangkan dampak negatif yang cukup besar bagi kesehatan lingkungan, maka perlu dilakukan upaya untuk menurunkan ekskresi nitrogen, asam urat dan produksi gas amonia dalam kandang unggas. Zat perangsang pertumbuhan yang ditambahkan ke dalam pakan broiler seperti beberapa antibiotika dan yucca saponin diketahui mampu menurunkan produksi gas amonia yang berasal dari litter (Carlile, 1984). Bahan lain yang juga mampu menurunkan produksi gas amonia adalah zeolit (Carlile, 1984; Xia et al., 1992). Terakhir, beberapa mikrobia juga diketahui memiliki kemampuan untuk menurunkan produksi gas amonia. Hasil penelitian menunjukkan bahwa produksi amonia dapat diturunkan dengan menggunakan mikrobia (Santoso et al., 1999). Kemungkinan mekanisme turunnya produksi gas amonia anatara lain adalah turunnya kadar nitrogen dan asam urat dalam feses sebagai akibat dari meningkatnya efidiensi penggunaan nitrogen oleh unggas. Oleh karena itu, penelitian ini dilakukan untuk mengevaluasi pengaruh produk fermentasi dari Bacillus subtilis terhadap kadar nitrogen, asam urat dan produksi amonia dalam kotoran broiler.

\section{MATERI DAN METODE}

Empat puluh ekor broiler umur 7 hari ditempatkan dalam kandang individu, dan didistribusikan ke dalam 4 kelompok perlakuan, yaitu satu kelompok diberi pakan yang mengandung $0 \%$ produk fermentasi dari Bacillus subtilis (PFBS) sebagai kontrol dan tiga kelompok lainnya diberi pakan yang masing-masing mengandung $0,5 \%, 1 \%$ atau 2\% PFBS. Pakan dan air minum diberikan ad libitum. Suhu kandang dipertahankan pada $25^{\circ} \pm$ $3^{\circ} \mathrm{C}$ dengan pemberian cahaya selama 14 jam dari jam 08.00 - 22.00. Broiler dipelihara selama $4 \mathrm{minggu}$, dan diberi pakan komersial dengan ME 3.200 kkal/kg dan protein $21 \%$.

Feses dikoleksi setiap hari selama empat minggu. Untuk mengurangi emisi maka feses untuk 5 ekor broiler pada setiap perlakuan disemprot dengan $5 \% \mathrm{HCl} 2$ kali/hari, sementara feses untuk lima ekor lainnya tidak disemprot fesesnya dengan $5 \% \mathrm{HCl}$. Feses yang disemprot dengan 5\% $\mathrm{HCl}$ kemudian dikeringkan dalam oven pada suhu $55^{\circ} \mathrm{C}$. Untuk setiap perlakuan, feses kemudian dicampur dan diaduk sampai homogen, dan selanjutnya disimpan dalam plastik pada suhu $25^{\circ} \mathrm{C}$ sebelum dianalisis kadar nitrogen, asam urat dan amonianya. Feses yang tidak disemprot $5 \% \mathrm{HCl}$ dikoleksi dan ditempatkan dalam ember tertutup untuk mengukur gas amonia setiap minggu.

Gas amonia diukur dengan gas detector (Kitagawa Gas Kenchikan AP-1), sementara asam urat dianalisis dengan menggunakan metode Dubbs et al. (1956) dan Pudelkiewicz et al. (1968) yang telah dimodifiasi oleh Santoso et al. (1999). Amonia diukur dengan kit (ammonia test Wako, Wako Pure Chemical Industries, Ltd Jepang). Total nitrogen, air dan abu dalam feses diukur dengan metode AOAC (1980).

Semua data dianalisis varians (Yoshida, 1975) dan jika berbeda nyata diuji lanjut dengan DMRT (Duncan, 1955).

\section{HASIL DAN PEMBAHASAN}

Tabel 1 menunjukkan pengaruh PFBS terhadap kadar N-urate dalam feses. Semakin tua umur brioler maka semakin rendah kadar N-urate. Pemberian 1\% PFBS menurunkan N-urate pada minggu ke 2, 3 dan 4.

Tabel 2 menunjukkan pengaruh PFBS terhadap kadar $\mathrm{N}$-amonia dalam 
Tabel 1. Pengaruh produk fermentasi dari Bacillus subtilis terhadap N-urate (mg/g BB)

\begin{tabular}{lllll}
\hline $\begin{array}{l}\text { Umur } \\
(\text { minggu })\end{array}$ & Kontrol & $0,5 \%$ PFBS & $1 \%$ PFBS & $2 \%$ PFBS \\
\hline 1 & $34,8 \pm 4,7^{\mathrm{ab}}$ & $30,9 \pm 4,1^{\mathrm{ab}}$ & $27,1 \pm 5,8^{\mathrm{a}}$ & $39,5 \pm 11,1^{\mathrm{b}}$ \\
2 & $19,4 \pm 0,9^{\mathrm{bc}}$ & $18,5 \pm 4,1^{\mathrm{b}}$ & $13,7 \pm 1,4^{\mathrm{a}}$ & $24,5 \pm 4,6^{\mathrm{d}}$ \\
3 & $14,1 \pm 2,5^{\mathrm{a}}$ & $11,6 \pm 3,3^{\mathrm{a}}$ & $14,7 \pm 3,2^{\mathrm{a}}$ & $20,0 \pm 4,0^{\mathrm{b}}$ \\
4 & $17,3 \pm 2,8^{\mathrm{b}}$ & $13,9 \pm 2,4^{\mathrm{ab}}$ & $12,5 \pm 2,4^{\mathrm{a}}$ & $16,6 \pm 2,5^{\mathrm{b}}$ \\
\hline \multicolumn{4}{r}{ Keterangan $: \begin{array}{c}\text { superskri yang berbeda kolom yang sama menunjukkan perbedaan nyata }(\mathrm{p}<0.05) \text { antar } \\
\text { perlakuan }\end{array}$}
\end{tabular}

feses. Kadar N-amonia tertinggi pada minggu ke 1 dan mencapai teredah pada minggu ke 3, dan kemudian naik kembali pada minggu ke 4. Pemberian 2\% PFBS menaikkan $\mathrm{N}$-amonia pada feses pada minggu ke 2 dan ke 3.

Tabel 3 menunjukkan kadar nitrogen, asam urat dan amonia dalam feses. Pemberian PFBS berpengaruh tidak nyata terhadap kadar nitrogen, asam urat dan amonia dan kadar abu dalam feses. Pemberian $1 \%$ PFBS secara nyata $(\mathrm{P}<0,05)$ menurunkan kadar air feses.

Tabel 4 menunjukkan pengaruh PFBS terhadap gas amonia. Pemberian 1\% PFBS menurunkan gas amonia pada minggu ke 4. Pada minggu ke 3 pemberian 2\% PFBS menurunkan gas amonia.

Hasil penelitian ini menunjukkan bahwa terjadi penurunan produksi gas amonia (Tabel 4) oleh PFBS. Hasil penelitian ini sesuai dengan hasil penelitian Santoso et al. (1999, 2001). Salah satu kemungkinan mekanismenya adalah turunnya kadar asam urat dalam feses.
Namun ternyata baik kadar nitrogen, asam urat maupun amonia dalam feses tidak menurun. Santoso et al. (1999) menunjukkan bahwa turunnya gas amonia dapat sebagian dijelaskan oleh turunnya kadar nitrogen dalam serum. Selain itu, Santoso et al. (1995, 2001) menemukan bahwa pemberian PFBS meningkatkan efisiensi penggunaan nitrogen, yang juga dapat menjelaskan fenomena tersebut. Tambahan pula, Bacillus subtilis menghasilkan subtilin yang menurunkan jumlah mikroflora yang memproduksi enzim urease dalam lumen saluran pencernaan (Visek et al., 1978). Santoso et al. (1999) menduga bahwa amonia yang diproduksi dari pemecahan asam urat atau urea diikat oleh senyawa yang belum diketahui yang dihasilkan oleh FPBS, sebab kadar amonia dalam feses tidak menurun. Kadar air dalam feses yang relatif tidak berbeda lebih mempersulit untuk memahami mekanisme penurunan amonia. Whyte (1993) menyatakan bahwa kadar air litter yang rendah akan menurunkan

Tabel 2. Pengaruh produk fermentasi dari Bacillus subtilis terhadap N-amonia (mg/g BB)

\begin{tabular}{lllll}
\hline $\begin{array}{l}\text { Umur } \\
\text { (minggu) }\end{array}$ & Kontrol & $0,5 \%$ PFBS & $1 \%$ PFBS & $2 \%$ PFBS \\
\hline 1 & $0,56 \pm 0,15$ & $0,49 \pm 0,10$ & $0,47 \pm 0,13$ & $0,62 \pm 0,16$ \\
2 & $0,43 \pm 0,96^{\mathrm{a}}$ & $0,35 \pm 0,11^{\mathrm{a}}$ & $0,38 \pm 0,13^{\mathrm{a}}$ & $0,64 \pm 0,12^{\mathrm{b}}$ \\
3 & $0,26 \pm 0,07^{\mathrm{a}}$ & $0,25 \pm 0,05^{\mathrm{a}}$ & $0,22 \pm 0,08^{\mathrm{a}}$ & $0,40 \pm 0,06^{\mathrm{b}}$ \\
4 & $0,32 \pm 0,02$ & $0,34 \pm 0,09$ & $0,27 \pm 0,05$ & $0,38 \pm 0,08$ \\
\hline
\end{tabular}

Keterangan : superskriyang berbeda kolom yang sama menunjukkan perbedaan nyata $(p<0.05)$ antar perlakuan 
Tabel 3. Pengaruh produk fermentasi dari Bacillus subtilis terhadap $\mathrm{N}$ total, asam urat dan amonia dalam feses $(\mathrm{mg} / \mathrm{g}$ BB)

\begin{tabular}{lllll}
\hline Variabel & Kontrol & $0,5 \%$ PFBS & $1 \%$ PFBS & $2 \%$ PFBS \\
\hline Total N & $321,6 \pm 11,3$ & $326,5 \pm 26,9$ & $329,8 \pm 10,2$ & $323,2 \pm 6,5$ \\
Asam urat & $111,4 \pm 3,9$ & $112,1 \pm 5,7$ & $115,5 \pm 6,6$ & $113,3 \pm 7,7$ \\
Ammonia & $2,48 \pm 0,16$ & $2,41 \pm 0,36$ & $2,31 \pm 0,33$ & $2,55 \pm 0,25$ \\
Abu (\%) & $13,7 \pm 0,6$ & $13,9 \pm 0,7$ & $14,0 \pm 0,7$ & $14,1 \pm 0,4$ \\
Air (\%) & $73,9 \pm 1,9$ & $74,6 \pm 1,7$ & $70,7 \pm 2,7$ & $75,2 \pm 1,2$ \\
\hline
\end{tabular}

Keterangan : superskriyang berbeda kolom yang sama menunjukkan perbedaan nyata $(\mathrm{p}<0.05)$ antar perlakuan

aktivitas mikrobia dalam mengkonversikan asam urat menjadi amonia, sehingga produksi gas amonia menurun. Namun, pada penelitian kadar air dalam feses tidak merupakan salah satu sebab menurunnya produksi gas amonia. Penelitian lebih lanjut diperlukan untuk menperjelas mekanisme penurunan produksi gas amonia.

Kadar normal gas amonia dalam kandang adalah sebesar 25 ppm. Meskipun hasil penelitian pada minggu ke 4 pada setiap perlakuan masih dalam taraf normal, namun sejalan dengan umur pemeliharaan yang semakin lama maka kadar gas amonia diprediksi akan melebihi 25 ppm pada kelompok kontrol dan 0,5\% PFBS. Oleh sebab itu, penambahan PFBS lebih dari $1 \%$ sangat penting pada umur pemeliharaan lebih dari 4 minggu. Penurunan gas amonia sebesar $45,6 \%$ pada kelompok $1 \%$ PFBS dan $53,3 \%$ pada kelompok $2 \%$ PFBS mempunyai kontribusi yang sangat besar dalam mengurangi polusi udara khususnya di kandang unggas. Hal ini tentu saja sangat menguntungkan baik bagi kesehatan unggas itu sendiri maupun bagi peternak. Diprediksi tingkat penurunan minimal dipertahankan pada tingkat ini pada pemeliharaan ayam broiler sampai umur potong.

\section{SIMPULAN}

Meskipun polusi udara akibat amonia menurun oleh suplementasi PFBS, namun bahaya polusi karena amonia pada tanah belum dapat diatasi. Amonia dalam feses akan dikonversikan ke nitrat oleh bateri nitrat sehingga $\mathrm{pH}$ menjadi rendah dan tingginya knsentrasi nitrat dalam air minum (Holthuijzen, 1993). Jadi, pemberian PFBS tidak sepenuhnya memecahkan masalah amonia. Kombinasi dari beberapa mikrobia sebagai suplemen mungkin dapat memecahkan masalah ini. Selain itu, kombinasi PFBS dengan zeolit sebagai feed additive (Xia et al., 1992) juga diduga mampu memecahkan masalah pencemaran yang disebabkan oleh nitrogen dalam feses.

Tabel 4. Pengaruh produk fermentasi dari Bacillus subtilis terhadap gas amonia (ppm)

\begin{tabular}{lllll}
\hline Minggu ke & Kontrol & $0,5 \%$ PFBS & $1 \%$ PFBS & $2 \%$ PFBS \\
\hline 3 & 2,4 & 3,2 & 2,8 & 0,6 \\
4 & 18,0 & 20,0 & 9,8 & 8,4 \\
\hline
\end{tabular}




\section{DAFTAR PUSTAKA}

AOAC. 1980. Official Methods of Analysis. $13^{\text {th }}$ ed. Washington, Association of Official Analytical Chemists.

Brodersen, J. R., J. R. Lindsey and I. E. Crawford. 1976. Role of environmental ammonia in respiratory mycoplasmosis of rats. Am. J. Path., 84: 115-121.

Carlile, F. S. 1984. Ammonia in poultry house: a literature review. World's Poultry Sci. J., 40: 99-113.

Dubbs, C. A., F. W. Davis and W. S. Adams. $\quad 1956 . \quad$ Simple microdetermination of uric acid. J. Biol. Chem., 218: 497-504.

Duncan, D. B. 1955. Multiple range and multiple F test. Biometrics, 11: 42.

Holthuijzen, Y. A. 1993. Environmental effects of the microbial degradation of poultry manure. World's Poultry Sci. J., 49: 173-174.

Pudelkiewicz, W. J., M. W. Stutz and L. D. Matterson. 1968. Determination of uric acid in avian excreta by the use od uricase and differential spectrophotometry. Poultry Sci., 47: 1274-1277.

Santoso, U. , S. Ohtani, K. Tanaka and M. Sakaida. 1999. Dried Bacillus subtilis culture reduced ammonia gas release in poultry house. Asian-Aust. J. Anim. Sci., 12: 806-809.

Santoso, U., K. Tanaka and S. Ohtani. 1995. Effect of dried Bacillus subtilis culture on growth, body composition and hepatic lipogenic enzyme activity in female broiler chicks. Bri. J. Nutr., 74: 523-529.

Santoso, U., K. Tanaka and S. Ohtani. 2001. Effect of fermented product from Bacillus subtilis on feed conversion efficiency, lipid accumulation and ammonia production in broiler chicks. Asian-Aust. J. Anim. Sci., 14: 333-337.

Visek, W. I. 1978. The mode of growth promotion by antibiotics. J. Anim. Sci., 46: 1447-1469.

Whyte, R. T. 1993. Aerial pollutants and the health of poultry farm. World's Poultry Sci. J., 49: 139-156.

Xia, Z., Z. Wand and R. Huang. 1992. Studies $\mathrm{n}$ the effects of local zeolite added to diets of growing pigs and broiler chickens. Recent Advances in Animal Production: Proc. The $6^{\text {th }}$ AAAP Anim. Sci. Cong., 3: 127.

Yoshida, M. 1975. Design of Experiments for Animal Husbandry. Pp. 126-143. Youkendo Press, Tokyo, Japan. 